INTERNATIONAL JOURNAL OF RESEARCHES IN BIOSCIENCES, AGRICULTURE \& TECHNOLOGY (C) VISHWASHANTI MULTIPURPOSE SOCIETY (Global Peace Multipurpose Society) R. No. MH-659/13(N) www.vmsindia.org

\title{
ACTIVATED RED MUD (ARM) IS USED FOR COLOR REMOVAL AS AN ADSORBENT FROM WASTE WATER.
}

\author{
Sanjay L Pal \\ Sevadal Mahila Mahavidyalaya \& Research Academy, Nagpur -440024 (M.S) INDIA. \\ E-mail: drsanjaypa124@gmail.com
}

\begin{abstract}
Red mud is a waste product generated during the extraction of aluminium from bauxite ore. Red mud was activated for the adsorption of color from live waste water. It has been observed that Activated Red Mud (ARM) shows good adsorption behavior on color. Adsorption phenomenon was studied using the parameters such as contact time, $\mathrm{pH}$, adsorbent dose and concentration of colored sample. A lab scale batch study was undertaken for the removal of color using Activated Red Mud (ARM). The maximum removal of color from waste water using Activated Red Mud (ARM) was found to be $86 \%$ at $\mathrm{pH}$ 3.0.Mechanism of adsorption is discussed in the paper.
\end{abstract}

Keywords: Red Mud, Color removal, Adsorption.

\section{Introduction:}

Due to rapid industrialization water is consumed in large volumes by textiles, tannery, paper and pulp, printing electroplating industries etc. Most of the industries use dyes and pigments to color their final products. Excessive use of dyes and pigments poses problems in the form of colored waste water. Even small quantities of dyes can color large water bodies. Color affects the nature of the water by inhibiting sunlight penetration thus reducing photosynthetic activity. Some dyes are carcinogenic and mutagenic (1). Hence there is a need to treat colored waste water before discharging into any receiving water bodies. Among the various available methods of color removal, adsorption appears to be most economical and effective treatment method (2).Activated carbon is the most efficient adsorbent for the removal of color from waste water but its high cost restricts the use of activated carbon. Therefore, there is an urgent need to search alternate economically viable adsorbent materials. Various studies have been carried out in search of suitable alternative adsorbents (3-6).

Red Mud is formed during the digestion in the Bayer's Process which is practiced for alumina production from bauxite. Mineralogically, red mud consists mainly of different forms of iron and aluminum oxide minerals, calcium and sodium aluminum silicates, various titanium compounds, etc. Oxidic constituents are the undissolved part of bauxite whereas silicates are formed from dissolved silica and alumina during desilication of aluminate liquors $(7,8)$.
Freshly sampled Red Mud had a water content $45 \%$ and $\mathrm{pH}$ 10.4. Chemical constituents of the activated red mud as determined by using standard method of chemical analysis are $\mathrm{Fe}_{2} \mathrm{O}_{3}-38.60 \%$, $\mathrm{TiO}_{2}-$ $18.90 \%, \quad \mathrm{SiO}_{2}-9.55 \%, \quad \mathrm{Al}_{2} \mathrm{O}_{3}-17.37 \%, \quad \mathrm{Na}_{2} \mathrm{O}-$ $6.67 \%$. Loss on ignition is $7.25 \%$ by weight. Porosity and density is determined by a mercury porosimeter and specific gravity bottles are 0.41 fractions $2.00 \mathrm{~g} / \mathrm{cm}^{3}$ respectively. The surface of the red mud as calculated by BET method was found to be $105 \mathrm{~m}^{2} / \mathrm{gm}$.

In the present study the red mud, a waste from bauxite industry, has been used as an adsorbent for color removal from waste water. A lab scale batch study was conducted using live colored waste water from laundry.

Experimental: The colored sample was procured from laundry located in Gandhibagh, Nagpur, India. It was characterized by estimating $\mathrm{pH}$, conductivity, turbidity, COD and BOD. The adsorbent (Red Mud) was procured from INDALCO (Indian Aluminium Company) Belgaum, Karnataka, India. The adsorbent was activated by washing several times with deionized water. Supernatant was decanted. The process was repeated several times. Dried adsorbent was kept in muffle furnace at $600^{\circ} \mathrm{C}$ for two hours.

Residual color or dye concentrations were determined by UV-visible spectrophotometer. One peak ( $\lambda$ max) was observed at 560nm.By comparing the percent transmittance at the maximum wavelength $(\lambda \max )$ before and after treatment the amount color removal was calculated. Distilled water was taken as the 
reference. Color removal calculation was made using following equation (9).

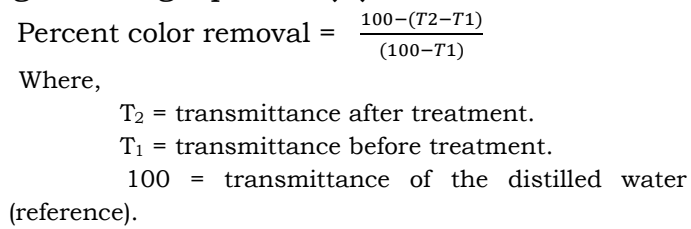

Optimization of contact time: In four different glass bottle, $100 \mathrm{ml}$ water sample was taken in each bottle.1gm of adsorbent i.e. activated red mud was added in each bottle and $\mathrm{pH}$ was adjusted to 6.These solution were shaken for different time intervals $(30,60,90$, and 120 minutes).The solutions were filtered through Whatmann filter paper No. 42 and then centrifuge. Remaining concentration of colored sample was determined by spectrophotometer (shown in Table No.1).

Table No.1: Effect of contact time on removal of color by Activated Red Mud (ARM).

$\begin{array}{ll}\mathrm{pH} & : 6 \\ \text { Initial } \mathrm{T} \%=\mathrm{T}_{1} & : 30 \\ \text { Adsorbent dose } & : 1 \mathrm{gm} / 100 \mathrm{ml} \\ \text { Settling time } & : 24 \text { hours }\end{array}$

\begin{tabular}{|l|c|c|c|}
\hline S.No. & $\begin{array}{l}\text { Contact Time } \\
\text { (min.) }\end{array}$ & $\mathbf{T}_{\mathbf{1}}=\mathbf{T}_{\mathbf{2}}$ & $\begin{array}{l}\text { \% Color } \\
\text { Removal }\end{array}$ \\
\hline 1. & 30 & 72.00 & 60.00 \\
\hline 2. & 60 & 74.00 & 62.85 \\
\hline 3. & 90 & 75.00 & 64.28 \\
\hline 4. & 120 & 75.00 & 64.28 \\
\hline
\end{tabular}

Contact time versus percent color removal

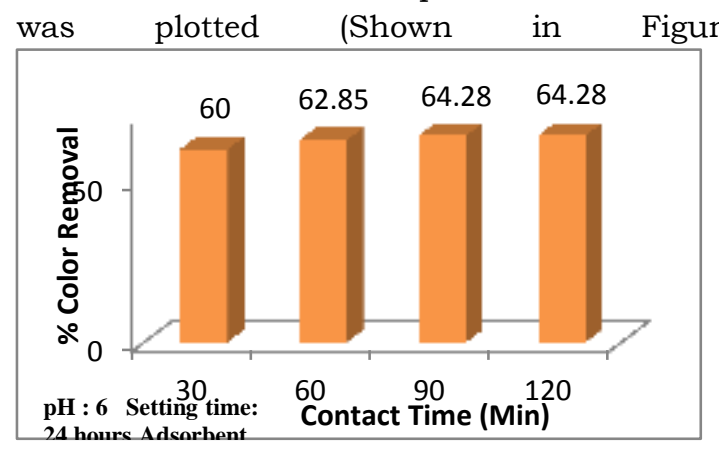

Optimization of $\mathrm{pH}$ : $1 \mathrm{gm}$ Activated red mud (ARM) was taken in $300 \mathrm{ml}$ glass bottles with $100 \mathrm{ml}$ water sample. The $\mathrm{pH}$ of colored sample was adjusted to 2, 4, 6,8 and 10 using $0.1 \mathrm{~N} \mathrm{HCl}$ or $0.1 \mathrm{~N} \mathrm{NaOH}$ on $\mathrm{pH}$ meter( model Biotech
B.T.I.). The glass bottles were placed on the shaking machine (Model No. TANCO, ANISO 9001: 2001 comp.). At a optimized contact time and then the samples were filtered through Whatmann filter paper No. 42. The filterate were centrifuge to separate adsorbent fines and percent color removal was determined using spectrophotometer (shown in Table No.2).

Table No.2: Effect of $\mathrm{pH}$ on removal of color by Activated Red Mud (ARM).

Contact time : 6 Initial $\mathrm{T} \%=\mathrm{T}_{1}: 30$ Adsorbent dose : 1gm/100ml Settling time : 24 hours

\begin{tabular}{|c|l|c|c|}
\hline S.N & $\mathrm{pH}$ & $\mathrm{T} \%=\mathrm{T}_{2}$ & $\begin{array}{c}\text { \% Color } \\
\text { Removal }\end{array}$ \\
\hline 1. & 2 & $89.00 \%$ & 84.28 \\
\hline 2. & 4 & $86.00 \%$ & 80.00 \\
\hline 3. & 6 & $73.00 \%$ & 61.42 \\
\hline 4. & 8 & $65.00 \%$ & 42.85 \\
\hline 5. & 10 & $55.00 \%$ & 35.71 \\
\hline
\end{tabular}

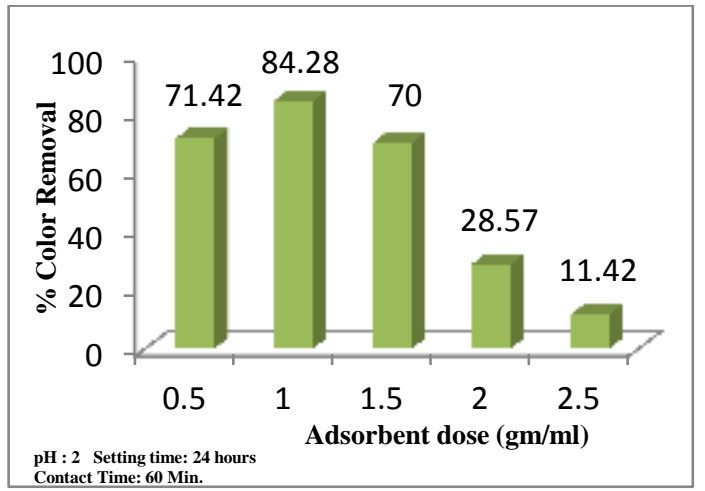

Effect of concentration: Effect of concentration at optimized dose, $\mathrm{pH}$ and contact time was studied (Shown in Table 4).

Table No.4: Effect of Concentration on removal of color by Activated Red Mud (ARM).

$\mathrm{pH}: 2 \quad$ Initial $\mathrm{T} \%=\mathrm{T}_{1}: 30$

Adsorbent dose : $2 \mathrm{gm} / 100 \mathrm{ml} \quad$ Settling

time : 24 hours 
Contact time : $60 \mathrm{~min}$.

\begin{tabular}{|c|l|l|c|}
\hline S.No. & $\begin{array}{c}\text { Concentra } \\
\text { tion(\%) }\end{array}$ & T\%=T & $\begin{array}{c}\text { \% Color } \\
\text { Removal }\end{array}$ \\
\hline 1. & 20 & $100.00 \%$ & 100.00 \\
\hline 2. & 40 & $100.00 \%$ & 100.00 \\
\hline 3. & 60 & $98.00 \%$ & 97.14 \\
\hline 4. & 80 & $96.00 \%$ & 94.28 \\
\hline 5. & 100 & $92.00 \%$ & 88.57 \\
\hline
\end{tabular}

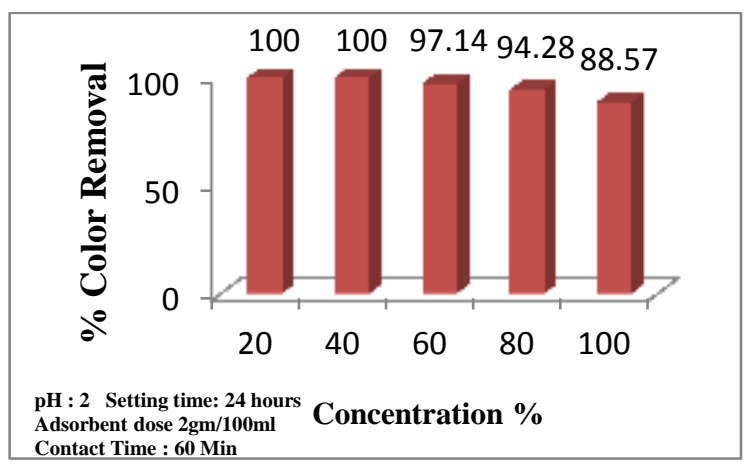

REFERENCES :

Mckay, G., Otterburn, M.S.and Jamal, Aga, J.A. Fuller's earth and fixed clay as adsorbents

for dye stuffs.Equilibrium and Rate constants. Water, Air and Soil Pollution, 24:307-322 (1985).

Process Design Manual for Carbon Adsorption USEPA Technology Transfer (1977).

Ramkrishna, K. and Virarraghvan, T., Wat. Sci. Tech., 36, No. 2-3,pp. 189-196 (1997).

Lambert,S.D., Graham,N.J.D., Solars, C.J.K., Flower,G.D., Wat. Sci. Tech., 36, No. 23,pp. 173-180 (1997).

Virarraghvan, T., Sapach, R. and Rao, G.A.K. Proc. 42 ${ }^{\text {nd }}$ Annual Com, Canada Waste Water Assoc. 85, (1992).
Geeta, K., Murthy, D.V.S. and Sastry, C.A., Journal Institution of Engineers,73, (1992).

Sigmond G. Csutkay J. Study on the disposal and utilization of bauxite residues-final report.Budapest:Unido,Aluterv-FKI, 1979.

Tumen F, Arsian N,Ispir U, Bildik M. Characterization of red mud fromseydisehir aluminium plant. FU J Sci Eng. 1993;5:40.

Mark T. Kennedy, Joe M. Morgan, Larry K.Benefield, A, Frank McFadden, "76 color

Removal from textile dye waste water : A case study. 47th Purdue Industrial Waste Conference Proceedings. pp. 727-741 (1992).

Namasivayam, C. and Arasi.D.J.S.E., Chemosphere,34, No.2, pp. 401-417 (1997).

Namasivayam, C. and Jayakumar, R. and Yamuna, R.T.,Waste Management, 14, pp.643-648 (1994). 